\title{
IMPLEMENTATION OF THE INTERNATIONAL REAL ESTATE TRANSACTIONS OPENNESS ASSESSMENT IN LATVIA
}

\author{
Janis Viesturs ${ }^{1}$, Mg.oec.; Armands Auzins ${ }^{2}$, Dr.oec., assoc.prof. \\ ${ }_{1,2}$ Riga Technical University
}

\begin{abstract}
In order to evaluate the ability of a country to attract an international investment real estate transaction, research was conducted to determine the criteria for and constituents of the International Real Estate Transactions Openness index as a set of systemic criteria. In Latvia, the assessment of such criteria is expressed as an index, and it was introduced in 2018, henceforth designated as the base year. The elaborated methodological solution for the assessment of International Real Estate Openness allows for the comparison of the institutional environment of international real estate transactions in any given country. In future it will be advisable to conduct an identical assessment of the institutional environment abroad (for example, in the Baltic states) to help foreign investors to evaluate the openness of each country to such transactions and to cross-check individual criteria at an international scale.
\end{abstract}

Key words: institutional economics, economic openness, international real estate transactions. JEL code: B25, R3, F41

\section{Introduction}

The purpose of this paper is do research on international real estate transactions in Latvia and to implement the methodological solution for assessment of International Real Estate Openness (hereinafter IREO - International Real Estate Openness). It would provide information on the International Real Estate Openness of the assessed country from the perspective of potential real estate transactions. In order to evaluate the ability of a country to attract international investment in real estate transactions as a set of systemic criteria indicating the openness to or potential readiness for international real estate alienation transactions of that country, the criteria and constituent elements have been chosen to determine its International Real Estate Openness. These criteria and constituent elements were discussed and evaluated through individual expert interviews, focus groups, seminars, as well as expert group surveys during period between 1 January 2018 and 30 June 2019. International real estate transaction experts participated in expert surveys twice through the Google Forms tool - (1) in IREO 2018 survey between 31 October 2018 and 30 June 2019 and (2) IREO 2019 survey between 20 January 2020 and 1 March 2020.

The comparative historical analysis of the economic theory of policy leads to the conclusion (Boettke et al., 2013) that the economic activities of actors and organisations, and the conduct of policy always proceed in a wider context of social factors, rather than in a vacuum. The history of global economics demonstrates that countries with a similar availability of industrial resources, or a similar geographical location and other factors beyond the social environment, may still differ greatly in their economic development. The scientific literature deploys various terms (Vitola, 2016) to describe the social factors driving economic development: for instance, habits, culture, religion, social capital, morals, ownership, fairness etc. The scientists of institutional economics share the view that institutional factors govern the reciprocal competitiveness between countries, and therefore economic development differs greatly from country to country.

In 1931, one of the representatives of the first generation of the school of institutional economics, John R. Commons, in his "Institutional Economics", when integrating the social dimension of human behaviour with economics theory, emphasized that the main subject of study in economics theory must be the transaction as an activity, coupled with the study of its actors, and that it is not only the market that regulates the economic process (Krilovs, 2014). It is also a significant feature in the 
view of those promoting the new institutional economy, for whom, contrary to the analysis of conventional microeconomics, studies focus on the transaction [i.e. event] rather than the act of transacting [i.e. process] (Seabrooke and Hwee Hong How, 2004). According to Commons' theory, the institutional infrastructure directs and regulates the market. Commons maintained that the state's economy must have transparent, fair and strong management to administer the laws and effectively maintain civic order. However, some governments may easily give in to corruption, subjecting legislation to the narrow business interests and generally ignoring the rule of law (Kaufman, 2008). Hence, institutional economics, according to Commons' theory, manifests itself as a collective activity with collective control, which is implemented through the governance of a network of authorities, companies, trade unions, families, churches, socially accepted standards, and other institutions, thus conditioning and regulating the activities of individuals. According to Commons, the institutions constitute a particular regime or a body of working rules (Kaufman, 2008), found in laws, case-law, human resource policies of companies, trade union regulations, collective agreements, socially accepted standards, religious doctrines, principles of ethics and traditions.

A representative of the second generation of the school of institutional economics, Clarence Edwin Ayres, in his work A Study of the Fundamentals of Economic Development and Cultural Change" (1944), analysed the social consequences of economic progress by asking the question - do institutions, such as companies, democracy, puritanism etc. "enable" the development of the industrial economy? And his answer was - if the institutional structure, which predominated in Western Europe for the last five centuries before the industrial revolution, had been strong enough to keep technological changes at ban then, no doubt, the changes would not have occurred. This means that the development of institutions can be both impeded and facilitated. This scientist asked the second essential question - what are the social consequences of economic progress? $\mathrm{He}$ concluded that the economy progresses if it is regulated by the market and by competition. However, in order to achieve social justice, any economic benefit must have not only a market-driven value, but also a social value, by which the state and social institutions contribute to public life.

Institutions are structures capable of restricting and impacting their subjects (Hodgson, 2002) and changing their habitual behaviour. The most influential representative of modern institutional economics, the editor of Journal of Institutional Economics, Geoffrey Hodgson, defines the institutions as an established and common system of social rules structuring social interaction. In his research he emphasizes the evolution of the institutions that entails changes in society's behaviour and a change in the habits of their followers.

Today, real estate transactions are related to several complicated and interdependent activities to meet the needs of different economic and social interests, which in their turn are related to an agreement on the transfer of real estate ownership, transfer (registration) and the financing of possessions, as well as to other activities connected with a transaction. In more recent research representatives of the new institutional economics, R. Coase and D. C. North, unlike the economists of the neoclassical school, have attributed a crucial role to transaction costs, emphasizing that such internal bureaucratic transaction costs (related to the administrative structure of a company) and external market transaction costs (related to the real estate market) arise during the transaction due to incomplete information, product valuation costs, ownership study and protection costs, as well as costs related to the drawing up and performance of contracts.

E. Williamson has greatly contributed to the research of transaction costs by mainly focusing on transaction costs in theoretical terms, comparing them to friction within physical systems which 
hinder movement. The economic equivalents of such friction are transaction costs, and the fact that parties who engage in these economic relationships do not always act in harmony - they often face misunderstanding and conflict, which leads to delays, additional costs and other impediments to the transaction (Williamson, 1981). Such real estate transactions, to use an analogy from physics, are therefore impeded by transaction costs; transaction-related costs which are relatively large, and payable in parallel with the real estate purchase price, by comparison with other commodity markets.

Given the wide range of opinions on the institutional aspects of the socio-economic relationships ("institutional richness" (Woestenburg et al., 2014), and admitting that no other word has been used more ambiguously and frequently in the contemporary social sciences than "institution" (Ayres, 1944), the authors maintain that studies of the institutional environment (for example, in Latvia - A. Vitola, M. Senfelde) which help to determine the general conditions for economic activity in certain countries, are of high value. Nevertheless, the stated goal of the research was to determine the criteria of the International Real Estate Openness of the country and to calculate the IREO index, involving a detailed assessment of the institutional environment of international real estate transactions.

\section{Methodology}

When analysing the openness to international real estate alienation transactions of a country, the scientific literature usually analyses one or several institutional aspects: for instance - (1) level of restrictions of international real estate transactions; (2) real estate transparency; (3) scope of real estate transactions or investments, or scope of investments, i.e. number, area, amount of investment or direct transactions in a certain period of time; (4) presence of measures aimed at attracting foreign investments, for instance, the offer of residence permits (investor visas) or even citizenship. However, these are merely fragmentary indicators of International Real Estate Openness. Therefore, in order to evaluate the ability of a country to attract international investment in real estate transactions as a set of systemic criteria indicating the openness to or potential readiness for international real estate alienation transactions of that country, the criteria and constituent elements have been chosen to determine its International Real Estate Openness. Afterwards, by using Delphi methods or eDelphi techniques for interviews (Pickard, 2007), in the period between 1 January 2018 and 30 June 2019, these criteria were discussed and evaluated through individual expert interviews, focus groups, seminars, as well as expert group surveys.

The experts for interviews were selected following several criteria:

1) Competence and interdisciplinarity. Representatives of 11 professions / occupations were selected - real estate brokers, company managers, developers, entrepreneurs, academic staff / researchers, managers, sworn notaries, valuers, lawyers / advocates, employees of credit institutions, and other real estate specialists who are considered to have optimal expertise in real estate transactions. This research thus qualifies as an interdisciplinary study. A strict principle to ensure that the number of representatives of any single profession / occupation constitutes not less than $5 \%$ and not more than $15 \%$ of the total number of survey subjects - was adhered to.

2) Assessment of competence. The assessment included an evaluation to establish whether each expert has the necessary expertise to participate in the research.

3) Experience. The experience of each expert was taken into account. The average duration of professional activity of the experts involved in the IREO 2018 survey was 12.9 years, whereas for the IREO 2019 survey it was 15.3 years). 
4) Good reputation. All the selected subjects represent companies and institutions with good reputation.

The authors of the research base the IREO criteria on the incidence of individual indicators in the scientific literature, reviews on indicators characterising the economic environment of different countries (for example, Tax Attractiveness Index, Financial Secrecy Index, Index of Economic Freedom, International Property Rights Index, Open Markets Index, Global Competitiveness Index, Global Trade Alert, Doing Business, Burden of Government Regulation), on structured interviews with industry experts, approbation of the acquired research results and insights, and discussions thereof in scientific seminars and conferences.

In order to assess the institutional environment of international real estate transactions, the following criteria and their elements were identified (each element was evaluated on a scale between 1 and 10).

1) Transparency of real estate and real estate transactions: (1) Safe real estate ownership; (2) Accurate and reliable information about real estate market and finances; (3) Performance of contracts and efficiency of courts; (4) Cross-compliance and transparency of data registered in the State Unified Computerized Land Register and the National Real Estate Cadastre; (5) Availability of information about real estate liens and the possibility of using the real estate; (6) Understandable tax system and regulations governing the real estate industry and predictability thereof.

2) Direct and indirect restrictions to foreigners in real estate alienation transactions with: (1) Agricultural and forest land; (2) Apartment property; (3) Commercial property (with land); (4) Land intended for household construction; (5) Private houses (with land).

3) Time of real estate alienation transaction: (1) Real estate ownership pre-registration phase; (2) Real estate ownership registration phase.

4) Transaction costs: (1) Transfer tax; (2) Broker services; (3) Legal services (notary fee, advocate or lawyer fees).

5) Administrative obstacles and level of bureaucracy - a need for various permits and references / statements, difficulty of acquiring thereof. For example, municipal permits for foreigners, offering of pre-emptive right etc.

6) Governmental policy encouraging international investments.

7) Governmental policy protecting international investments.

8) Professional competency of the persons involved in the industry: (1) Real estate agents; (2) Notaries; (3) Advocates / lawyers; (4) Real estate appraisers; (5) Economists; (6) Employees of the Land Register; (7) Employees of the State Land Service; (8) Employees of the municipalities; (9) Real estate managers; (10) Real estate insurers; (11) Real estate developers; (12) Employees of the credit institutions.

9) Development of technologies related to real estate transactions regarding: (1) Due diligence of the real estate; (2) Obtaining and collecting data and information; (3) Document circulation (including registration of ownership).

10) Activities of credit institutions encouraging real estate transactions. 


\section{Identification of Latvia's Openness to International Real Estate Transactions Index}

60 international real estate transaction experts participated in expert surveys twice through the Google Forms tool - (1) in IREO 2018 survey between 31 October 2018 and 30 June 2019 and (2) IREO 2019 survey between 20 January 2020 and 1 March 2020.

When determining the relative significance (weight) of each criterion, the set of individual criteria as a numeric quantity is expressed as an index (formula 1) to characterise the relative changes in the country's International Real Estate Openness, in order to determine the index periodically - on a yearly basis - and to analyse each criterion separately. The calculations demonstrate that IREO of Latvia 2019 in comparison to 2018 has dropped from 5.89 to 5.61 (Table 1).

Table 1

IREO 2018 and IREO 2019 indexes

\begin{tabular}{|c|c|c|c|c|c|c|}
\hline No. & REO criterion & $\begin{array}{c}\text { Assessment } \\
2018 \\
\text { (average.) }\end{array}$ & $\begin{array}{c}\text { Assessment } \\
2019 \\
\text { (average.) }\end{array}$ & $\begin{array}{c}\text { Relevance } \\
\text { of criteria } \\
\text { (w1-w7), } \\
\% \\
\end{array}$ & $\begin{array}{c}\text { Adjusted } \\
\text { criteria } \\
\text { assessment } \\
\text { in } 2018\end{array}$ & $\begin{array}{c}\text { Adjusted } \\
\text { criteria } \\
\text { assessment } \\
\text { in } 2019\end{array}$ \\
\hline a & Transparency & 6.93 & 6.71 & 0.13 & 0.90 & 0.87 \\
\hline b & Direct and indirect restrictions & 7.17 & 7.07 & 0.14 & 1.00 & 0.99 \\
\hline c & Time & 6.80 & 6.89 & 0.05 & 0.34 & 0.34 \\
\hline d & Transactions costs & 5.03 & 5.27 & 0.08 & 0.40 & 0.42 \\
\hline e & Administrative obstacles and level of bureaucracy & 4.56 & 4.32 & 0.10 & 0.46 & 0.43 \\
\hline$f$ & Governmental policy encouraging international investments & 4.12 & 3.63 & 0.11 & 0.45 & 0.40 \\
\hline $\mathrm{g}$ & Governmental policy protecting international investments & 5.00 & 4.42 & 0.10 & 0.50 & 0.44 \\
\hline $\mathrm{h}$ & $\begin{array}{l}\text { Professional competency of the persons involved in the } \\
\text { industry }\end{array}$ & 6.99 & 6.93 & 0.09 & 0.63 & 0.62 \\
\hline $\mathrm{i}$ & Development of technologies related to real estate transactions & 6.49 & 6.49 & 0.09 & 0.58 & 0.58 \\
\hline j & $\begin{array}{l}\text { Activities of credit institutions encouraging real estate } \\
\text { transactions }\end{array}$ & 5.63 & 4.53 & 0.11 & 0.62 & 0.50 \\
\hline \multicolumn{2}{|c|}{ Total } & 58.80 & 56.26 & 1.00 & 5.89 & 5.61 \\
\hline
\end{tabular}

Source: author's calculation based on research data

IREO index is calculated according to the formula:

$$
\begin{gathered}
w_{1} * \sum_{n=1}^{6} \frac{a_{n}}{6}+w_{2}\left(0,09\left(b_{1}+b_{3}\right)+0,10\left(b_{4}+b_{5}\right)+0,62 * b_{2}\right)+w_{3} * \sum_{n=1}^{2} \frac{c_{n}}{2}+w_{4} * \sum_{n=1}^{3} \frac{d_{n}}{3}+w_{5}(e+g)+ \\
w_{6}(f+j)+w_{7} *\left(\sum_{n=1}^{12} \frac{h_{n}}{12}+\sum_{n=1}^{3} \frac{i_{n}}{3}\right)
\end{gathered}
$$

where:

IREO - Openness to International Real Estate Transactions index of the country

$a_{1}-a_{6}-$ elements of IREO criterion "Transparency of real estate and real estate transactions";

$b_{1}-b_{5}-$ elements of IREO criterion "Direct and indirect restrictions to foreigners in real estate alienation transactions";

$c_{1}-C_{2}-$ elements of IREO criterion "Time of real estate alienation transaction";

$d_{1}-d_{3}-$ elements of IREO criterion "Transaction costs";

$e-$ Administrative obstacles and level of bureaucracy;

$f-$ Governmental policy encouraging international investments;

$g-$ Governmental policy protecting international investments;

$h_{1}-h_{12}$ - elements of IREO criterion "Professional competency of the persons involved in the industry";

$i_{1}-i_{3}$ - elements of IREO criterion "Development of technologies related to real estate transactions";

$j-$ Activities of credit institutions encouraging real estate transactions;

$w_{1 . . .} w_{7}-$ Relative weight of criterion, $w_{1}+w_{2}+w_{3}+w_{4}+w_{5} * 2+w_{6} * 2+w_{7} * 2=1$

$n$ - quantity of elements of each IREO criterion. 


\section{Conclusions, proposals, recommendations}

1) The calculation of the IREO index shows that the International Real Estate Openness of Latvia in 2019, as compared with 2018, has decreased (the index has dropped from 5.89 to 5.61).

2) The elaborated methodological solution for assessment of the International Real Estate Transactions Openness index allows a cross-comparison of the institutional environment of international real estate transactions in 2018 and 2019. In future it is planned to determine this index regularly (on a yearly basis) as a calculation of the IREO index, taking 2018 as the base year of the calculation. The following persons are advised to become acquainted with it: (1) employees of the state and municipal authorities, who are responsible for promoting foreign investments; (2) members of the Latvian Real Estate Association; (3) Members of the Latvian Chamber of Commerce and Industry; (4) Members of the Foreign Investors Council in Latvia; (5) Foreign investors, and (6) other persons whose professional activity is related to international real estate transactions.

3) Of all the IREO criteria in 2018 and 2019, the lowest score was received by "Administrative obstacles and level of bureaucracy", "Governmental policy encouraging international investments", "Governmental policy protecting international investments", and "Investment encouraging activities of credit institutions". These are indicators that public authorities must take into account in order to prove their intention to attract foreign investments, as well as to provide grounds to foreign investors for a cautious approach to making decisions on investments in Latvia.

4) In future it is advisable to conduct an equal assessment of the institutional environment of the IREO abroad (for example, in the Baltic states) to help foreign investors to evaluate the openness of each country to such transactions and to cross-check individual criteria at the international scale.

\section{Bibliography}

1. Ayres, C.E. (1944). Theory of Economic Progress. A Study of the Fundamentals of Economic Development and Cultural Change. University of North Carolina Press. Retrieved: http://cas2.umkc.edu/economics/Institutional/Readings/Ayres/tep/teptitle.html Access: 16.09.2019

2. Boettke, P.J., Coyne, Ch., Leeson, P.T. (2013). Comparative Historical Political Economy. Journal of Institutional Economics, Volume 9, Issue 3, pp. 285-301. https://doi.org/10.1017/S1744137413000088

3. Hodgson, G. (2002). The Evolution of Institutions: An Agenda for Future Theoretical Research. Constitutional Political Economy, Volume 13, pp. 111-127. https://doi.org/10.1023/A:1015301101712.

4. Seabrooke, W., Hwee Hong How, H. (2004). Real Estate Transactions: an Institutional Perspective. In: International Real Estate. An institutional approach. Ed. by Seabrooke, W., Kent, P., Hwee Hong How, H. Oxford: Blackwell Publishing Ltd., p. 5.

5. Kaufman, B.E. (2008). The Institutional Economics of John R. Commons: Complement and Substitute for Neoclassical Economic Theory. Socio-Economic Review, Volume 5, Issue 1, pp. 3-45. https://doi.org/10.1093/ser/mw/016

6. Krilovs, L. (2014). Ekonomiskas domas retrospekcija. Ziatniska monografija (A History of Economic Thought. Scientific Monograph). Riga: RTU izdevnieciba, pp. 125-127.

7. Pickard, A.J. (2007). Research Methods in Information. London: Facet Publishing, pp. 126-127.

8. Vitola, A. (2016). Instituciju socialekonomiskas ietekmes novertesana. Promocijas darbs (An Evaluation of the Socioeconomic Impact of Institutions. PhD thesis). Riga: RTU Izdevnieciba, p. 153.

9. Williamson, O.E. (1981). The Economics of Organization: The Transaction Cost Approach. The American Journal of Sociology, Volume 87, No. 3, pp. 548-577. Retrieved: http://unige.ch/sciencessociete/socio/files/1114/0533/6204/Williamson_1981.pdf Access: 21.11.2019

10. Woestenburg, A., van der Krabben, E., Spit, T. (2014). Institutions in rural land transactions. Journal of European Real Estate Research, Volume 7, Issue 2, pp. 216-238. http://dx.doi.org/10.1108/JERER-01-20140005 